\title{
The alien flora of the Rzeszów Foothills
}

\author{
Małgorzata Jaźwa ${ }^{1} \&$ Agata Stadnicka-Futoma ${ }^{2 *}$
}

\begin{abstract}
${ }^{1}$ Institute of Botany, Faculty of Biology and Earth Sciences, Jagiellonian University, Kopernika 27, 31-501 Kraków, Poland ${ }^{2}$ Institute of Botany, Faculty of Biology and Agriculture, University of Rzeszów, Zelwerowicza 4, 35-601 Rzeszów, Poland

* corresponding author (e-mail: astadnicka@ur.edu.pl)
\end{abstract}

\begin{abstract}
The aim of the study was to analyze the synanthropic flora of the Rzeszów Foothills (south-eastern Poland). Floristic studies were carried out in years 2007-2013 using the cartogram method in the ATPOL system ( $2 \times 2 \mathrm{~km}$ square grid). Here we present the numerical data (number of species in each historical-geographical group, families most frequently represented by anthropophytes), show the proportion of specific growth forms and describe habitat preferences. The Rzeszów Foothills region had already been shown as strongly impacted by anthropogenic pressures. The total number of vascular plant species detected was equal to 1115; among them, the synanthropes represent about 30\%. Also the index of synanthropy was calculated to confirm strong anthropogenic transformation of the studied area. In the presented study, 47 invasive plant species were discovered in the region. Moreover, the role and distribution of the most interesting and invasive of the synanthropic species was analyzed based on their negative impact on the native flora. We also identified plant species with high invasive potential and indicated causes of their appearance and spread.
\end{abstract}

Key words: synanthropic flora, vascular plant, anthropophytes, invasive plants

\section{Introduction}

Species of foreign origin and the issue of biological invasions they cause have been widely recognized in individual countries and worldwide (e.g. Pyšek et al. 2002; Lambdon et al. 2008; Tokarska-Guzik et al. 2014). Currently, a strong emphasis is put on environmental changes and economic losses caused by invasive species (Mack et al. 2000; Pimentel et al. 2001; Hulme et al. 2009; Tokarska-Guzik et al. 2011).

This paper provides an overview of alien flora of the Rzeszów Foothills, which has already been strongly modified by anthropogenic pressures. In the presented study, 47 invasive plant species were discovered in the region. Most of those species are epecophytes.

Invasive species are allochthonic species with a high expansiveness that spread naturally or involving human actions; they compete effectively with indigenous species, threatening the native flora and fauna of the ecosystem and may contribute to the extinction of native species (Inderjit et al. 2008). Invasive species represent a serious threat to the global biodiversity and can be a serious problem in protected areas. Most of invasive species occur in areas strongly affected by humans.
Such habitats include urban areas (including ruderal communities), agricultural and forest areas (particularly, forest monocultures) and abandoned areas that had been used by people extensively. Changes in land use are often associated with political and/or sociological processes, such as migrations of rural populations to urban areas and renunciation of crops, resulting in set-aside land portions. Those areas are sources of the spread of invasive species, but also provide a fascinating area of research on the phenomenon of intra- and interspecific competition among plants (Bais et al. 2003; Callaway et al. 2005; Moroń et al. 2009).

A threat evaluation was performed for particular species on the basis of numbers of localities, the diversity of preferred habitats recorded and their current (over the last decade) tendency to colonize new localities.

\section{Material and methods}

\subsection{Study area}

The research was performed in the Rzeszów Foothills, the area located in the south-eastern Poland. This region encompasses the southern part of the Sandomierz 


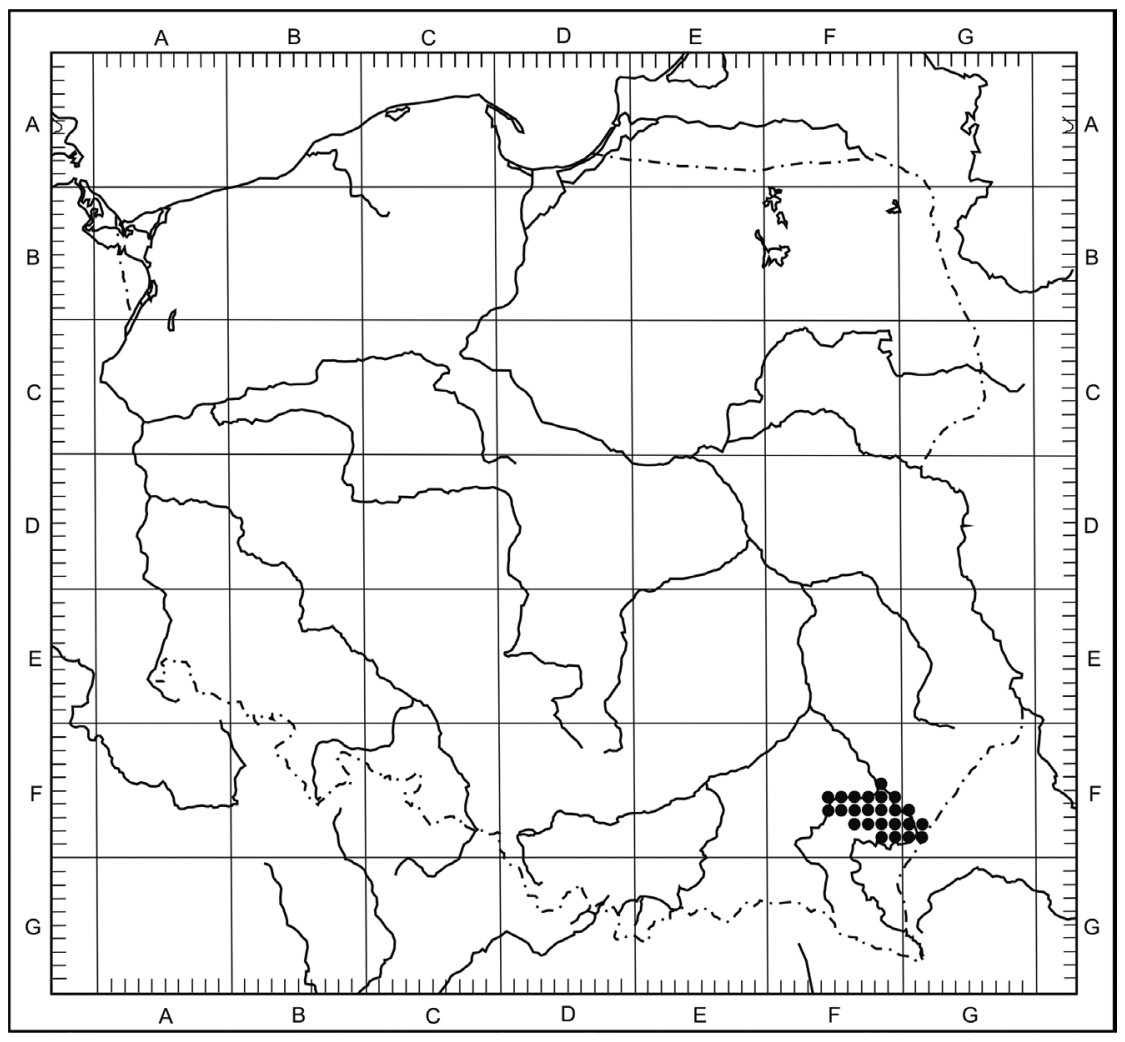

Fig. 1. Location of the research area within the grid of ATPOL

Basin and stretches between the San and the Wisłok river valleys from Rzeszów to Przemyśl (Fig. 1). The area lies between mountains and the lowland sub-province of Central Europe (Szafer \& Zarzycki 1977). According to the physical-geographical classification (Kondracki 1994, 2011), the area belongs to the province: Western Carpathians with Subcarpathia, the sub-province: North Subcarpathia, the macro-region: Sandomierz Basin, the region: Rzeszów Foothills. The study area comprised approximately $860 \mathrm{~km}^{2}$ (Kondracki 2011).

The Rzeszów Foothills environment has been heavily transformed by human activity. The studied region is composed mainly of agricultural landscapes, dominated by cultivations of cereals and root crops, with numerous but relatively poor meadow communities. Bigger cities like Jarosław, Kańczuga, Łańcut, Pruchnik, Przeworsk are important concentrations of synanthropic flora. Surrounding villages are characterized by compact and dense building cover. In many villages, the architectural style can be referred to as suburbs. It manifests itself by the presence of sidewalks along roads, planted squares and many areas related to minor industrial facilities. Such composition of plant communities results in a large proportion of ruderal habitats in the studied area.

\subsection{Field methods}

The investigated area comprises 2 large ATPOL squares (100 km x $100 \mathrm{~km})$ : FF, FG with 23 smaller squares (10 km x $10 \mathrm{~km})$ : FF 48, 54-56, 58, 59, 64-69, 76-79, 88, 89, FG: 60, 70, 71, 80, 81, which comprise 347 basic squares $(2 \mathrm{~km} \times 2 \mathrm{~km})$. The total area of the study covers approx. $860 \mathrm{~km}^{2}$ (Kondracki 2011). Field work was carried out in years 2007-2013 during the vegetation growing seasons. A cartogram method was used in the study. The cartographic grid used was based on the ATPOL network (Zając 1978).

\subsection{Data analysis}

Nomenclature of plant species was given according to Mirek et al. (2002) and names of plant communities were given according to Matuszkiewicz (2006).

The list of alien species in the Foothills of Rzeszów was established on the basis of other publications concerning the whole country (Zając et al. 1998; Mirek et al. 2002; Tokarska-Guzik 2005a, 2005b; TokarskaGuzik et al. 2014), and of local studies (Ochyra 1974; Łuczycka-Popiel 1983; Wilk 2004; Jaźwa 2012). Synanthropic flora analysis was performed on the basis of the geographical and historical classification of synanthropic plants (Kornaś \& Medwecka-Kornaś 2002). Archaeophytes were distinguished based on the work of Zając (1979, 1987a, 1987b, 1988), kenophytes were determined on the basis of the work of Zając et al. (1998) and Tokarska-Guzik (2005b). Based on the types of colonized habitats, species were assigned to relevant groups of kenophytes. Invasive species were 
chosen according to the definition contained in articles of Richardson et al. (2000), Pyšek et al. (2004) and Tokarska-Guzik (2005b) and based on the work of Tokarska-Guzik et al. (2014). The native taxa were not included in the group of invasive species; however, they can also have invasive character (Valéry et al. 2009; Zając \& Zając 2009).

To evaluate the degree of synanthropy of communities in the study area, several indicators defined by Jackowiak $(1990,1998)$ were used. They describe participation of particular geographic-historical groups in relation to the total analyzed flora and particular groups. In the below formulas, the following symbols were used: An - anthropophytes, Ar - archaeophytes, D - casual aliens, $\mathrm{Kn}$ - kenophytes (neophytes), $\mathrm{M}$ - metaphytes, established species, $\mathrm{Sp}$ - native plants. For the analysis, the following indicators were selected:

Total anthropophytization index:

$$
W A n_{t}=\frac{M}{S p+A n} \times 100 \%
$$

Total kenophytization index:

$$
W K n_{t}=\frac{K n-D}{S p+A n} \times 100 \%
$$

Total archaeophytization index:

$$
W A r_{t}=\frac{A r}{S p+A n} \times 100 \%
$$

Flora modernization index:

$$
W M=\frac{K n}{M} \times 100 \%
$$

Index of floristic fluctuation:

$$
W F=\frac{D}{S p+A n} \times 100 \%
$$

\section{Results}

3.1. Geographical and ecological characteristic of established alien flora in the Rzeszów Foothills

The flora of the Rzeszów Foothills is represented by 1115 species of vascular plants (not including unconfirmed literature data). The list of naturalized alien plant species for the Rzeszów Foothills comprised 237 species (Appendix 1), which is about $21.3 \%$ of the total flora. There are 101 archaeophytes, 131 kenophytes and 5 species classified with an uncertain status (Fig. 2). In addition, 12 species were considered as apophytes and 53 - as diaphytes. The kenophyte group was represented by epecophytes (locally naturalized -7 species; naturalized-76), hemiagriophytes naturalized -33 and holoagriophytes naturalized - 14 (Fig. 3). Most of the kenophytes were naturalized epecophytes. Percentages of each group of synanthropic species in the flora of Poland and selected adjacent areas follow (Table 1).

Alien species were represented by 51 families. Families that were the most frequently (Fig. 4) represented in the established alien flora were: Asteraceae (39 species), Brassicaceae (24), Poaceae (18), Rosaceae (14) and Fabaceae (13). 21 families were represented by one species. Families like Asteraceae, Chenopodiaceae, Rosaceae were dominated by kenophytes. Archaeophytes were mostly represented in Fabaceae, Lamiaceae, Malvaceae and Caryophyllaceae.

With respect to different vegetation growth forms, the alien flora was characterized by a high number of annuals (therophytes -113 species). There was also a high proportion of long-lived perennial herbs (especially, hemicryptophytes - 50) and woody plants (phanerophytes - 29). Archaeophytes were represented mainly by annuals, kenophytes - by annuals and hemicryptophytes.

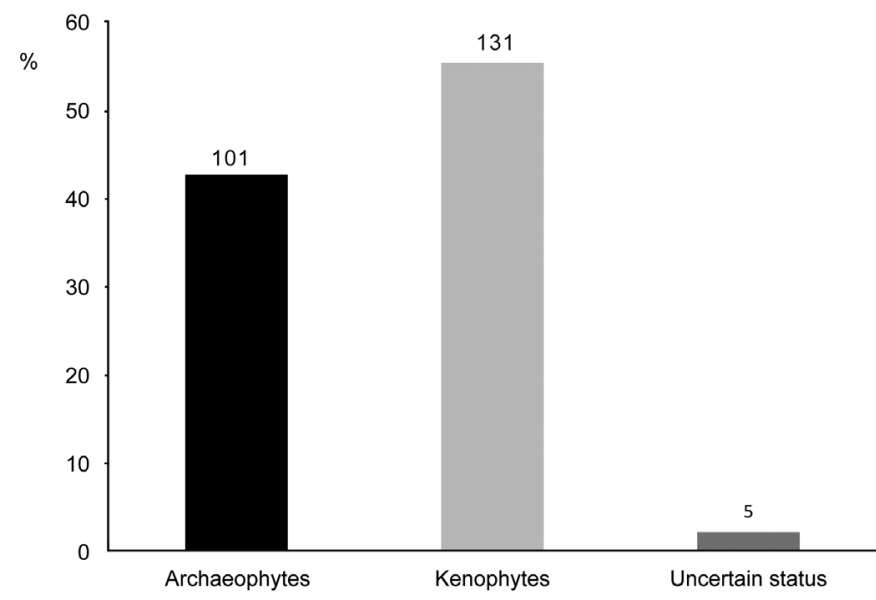

Fig. 2. The geographical and historical classification of synanthropic plants in the Rzeszów Foothills 
Table 1. Percentages of each group of synanthropic species in the flora of Poland and selected adjacent areas

\begin{tabular}{lcccc}
\hline & Poland & $\begin{array}{c}\text { Rzeszów } \\
\text { Foothills }\end{array}$ & $\begin{array}{c}\text { Przemyśl } \\
\text { Foothills }\end{array}$ & $\begin{array}{c}\text { E Sandomierz } \\
\text { Basin }\end{array}$ \\
\hline Archaeophytes & 17 & 33 & 37 & 36 \\
Naturalized kenophytes & 39 & 45 & 40 & 33 \\
Uncertain status & 2 & 2 & 4 & 6 \\
Efemerophytes & 42 & 20 & 19 & 25 \\
\hline
\end{tabular}

The majority of alien species came from different parts of Europe (64) and most of them were archaeophytes (44), while kenophytes originated mostly in North America (46). Also a large group of alien species came from Eurasia (26 archaeophytes and 21 kenophytes) and Asia (13 archaeophytes and 20 kenophytes). According to the phytosociological classification (Matuszkiewicz 2006), a majority of alien species cannot be associated with any community ( 84 species). Both archaeopytes and kenophytes are significantly represented in plant communities from the class Stellarietea mediae and Artemisietea vulgaris.

Taxa mentioned in the Appendix, generally occurred in ruderal or segetal habitats, but also penetrated natural ones. Ruderal habitats were dominated by kenophytes and segetal habitats - by archaeophytes. Semi-natural habitats were occupied by a large number of species, where as natural habitats were penetrated by few, mostly invasive species, for example Echinocystis lobata or Padus serotina. Several species, such as Capsella bursapastoris (342 localization), Erigeron annuиs (336) or
Vicia grandiflora (328), had a wide ecological spectrum and they were found in various types of habitats with a huge number of localities.

The study area was dominated by alien species (almost half of those noted) which were very rare (to 13 stands) and, in most cases, could be classified as kenophytes. Rare (14-57 stands) and common species (290-347 stands) formed another well-represented group. Rare species were dominated by kenophytes and common species were mostly represented by archaeophytes.

In the presented study, 47 invasive plants were identified in the studied region. Nine of them were considered as "weeds" and 15 were found to be "transformers". The remaining ones were classified as "not harmful". Epecophytes were the largest group of invasive species (18); the smallest group were archaeophytes (4) represented only by "weeds".

To evaluate the degree of synanthropy of communities in the study area, several indicators were considered: total anthropophytization index $-21.3 \%$, total kenophy-

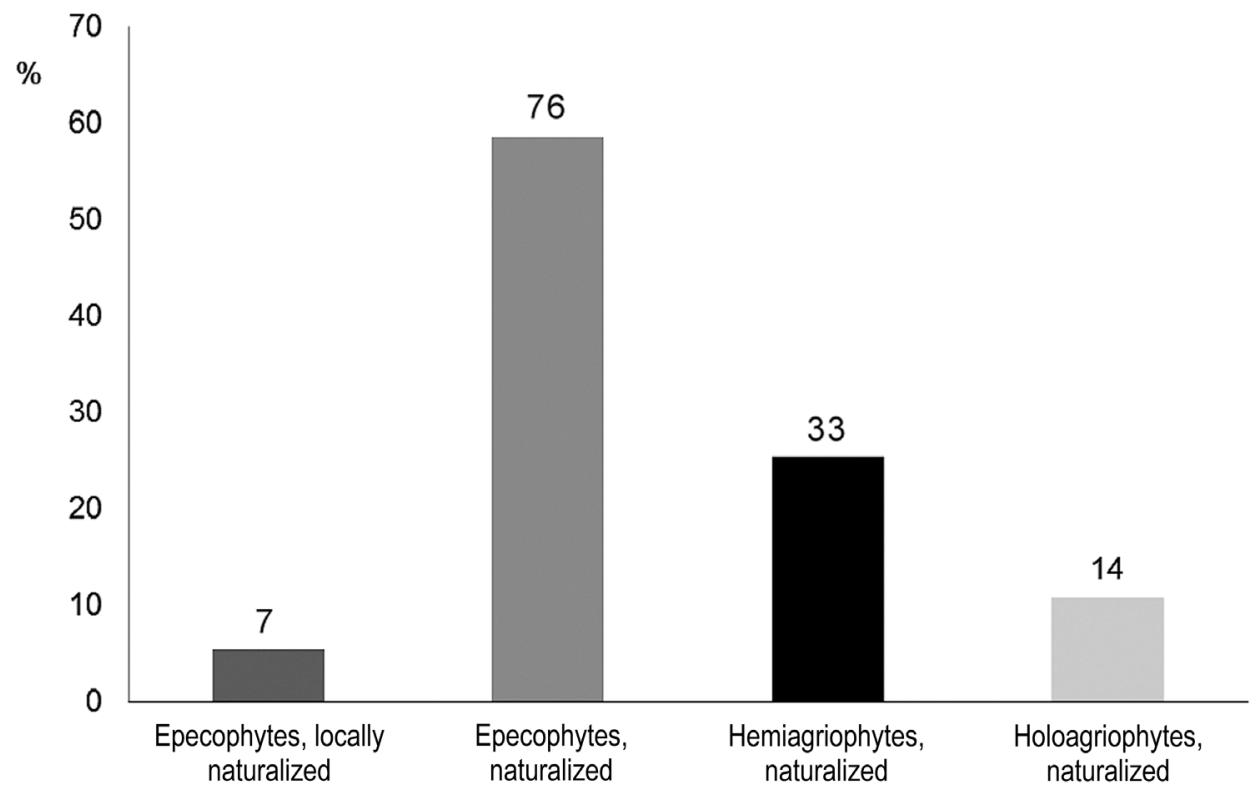

Fig. 3. The composition of kenophytes groups in the Rzeszów Foothills 


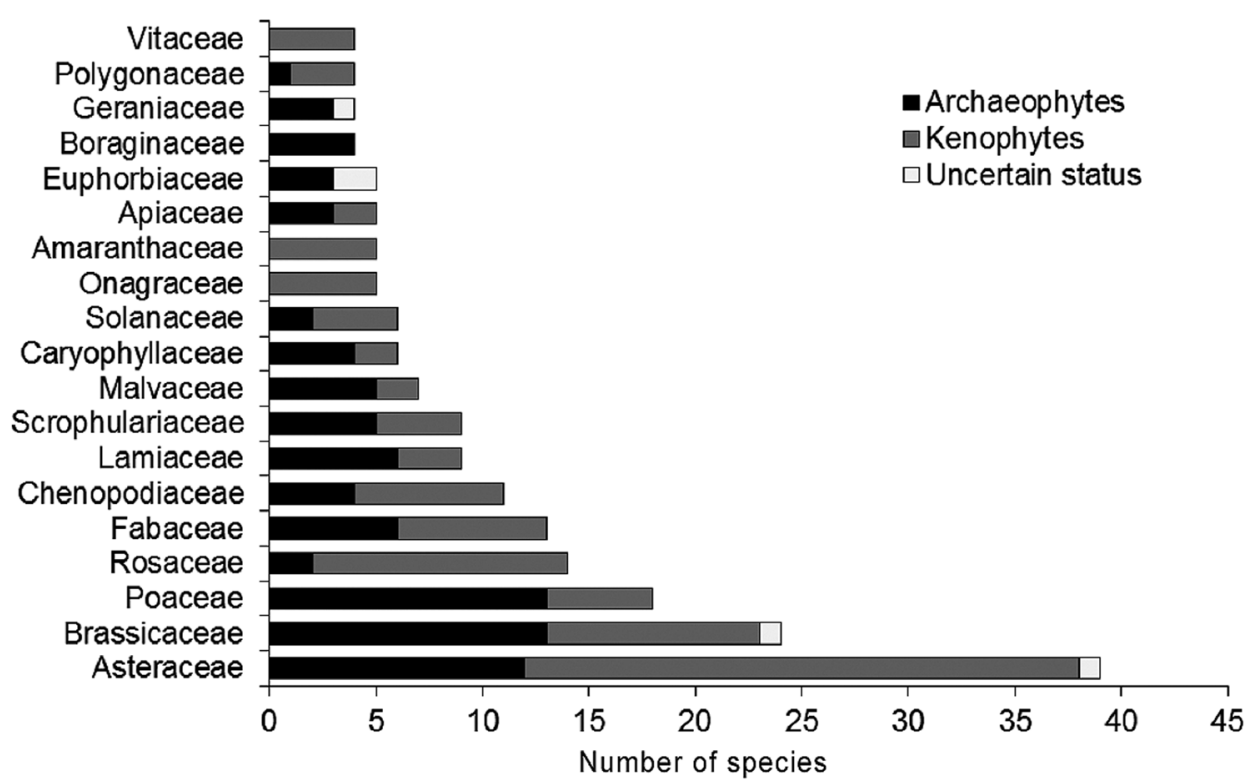

Fig. 4. The most frequently represented families in the naturalized alien flora of the Rzeszów Foothills

tization index $-11.7 \%$, total archaeophytization index $-9.1 \%$, flora modernization index $-77.6 \%$ and index of floristic fluctuation $-4.8 \%$.

\section{Discussion}

The Rzeszów Foothills remains under strong anthropogenic influence. More than $70 \%$ of the area is occupied by segetal and ruderal habitats. A small number of natural and semi-natural plant communities occur sporadically. The spreading of the synanthropic plants is greatly facilitated by $(i)$ a highly developed transportation network: local and provincial roads, railway lines (extending throughout the whole terrain) and (ii) placement in valleys of large rivers (San, Wisłok, Mleczka) and their tributaries. Moreover, in recent years, a large number of new alien species was introduced as a consequence of the highway construction. It is reflected in the number of synanthropic species, which comprise up to $26 \%$ of the vascular plants. The next few years are likely to exhibit further significant changes in the local diversity of vascular plants due to the completion of the

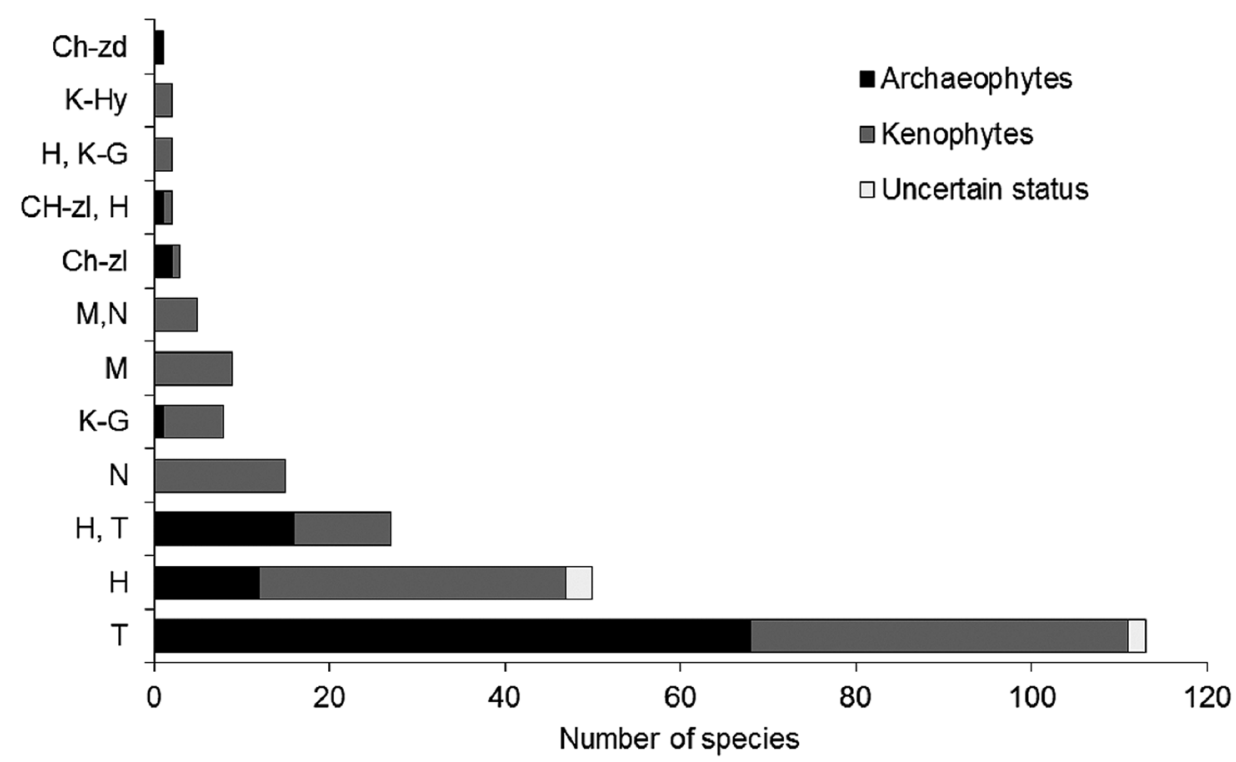

Fig. 5. The contribution of growth-forms to the naturalized alien flora of Rzeszów Foothills

Explanations: labels, $\mathrm{M}$ - megaphanerophytes, $\mathrm{N}$ - nanophanerophytes, Ch-zd - ligneous chamaephytes, Ch-zl - herbaceous chamaephytes, $\mathrm{H}$ - hemicryptophytes, T - therophytes, K-G - geophytes, K-Hy - hydrophytes 


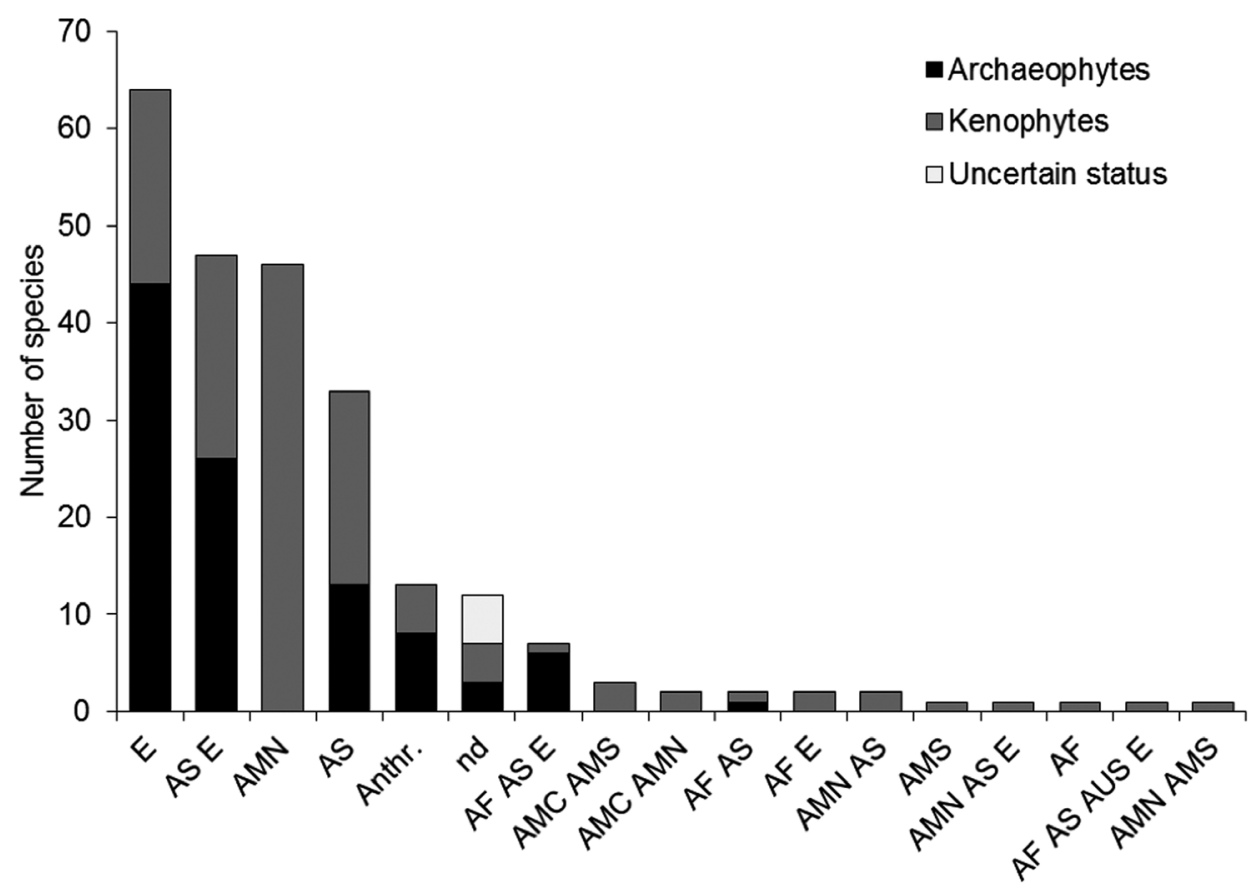

Fig. 6. Geographical origin of naturalized alien flora in the Rzeszów Foothils

Explanations: AF - Africa, AMC - Central America, AMN - North America, AMS - South America, AS - Asia, AUS - Australia, E - Europe, Anthr. - taxon od anthropogenic origin, nd - not definied

highway (new ecological corridors). Such a dynamic situation suggests a need for constant monitoring of alien species and the importance of further research in the studied region.

The percentages of individual groups of synanthropic species in the studied area differed significantly from those evaluated for the whole country (Tokarska-Guzik et al. 2014 and references cited therein). A greater proportion of archaeophytes was noticeable, which is associated mainly with a large proportion of segetal habitats, which are dominated by common weed archaeophytes. The fraction of kenophytes is also increased in relation

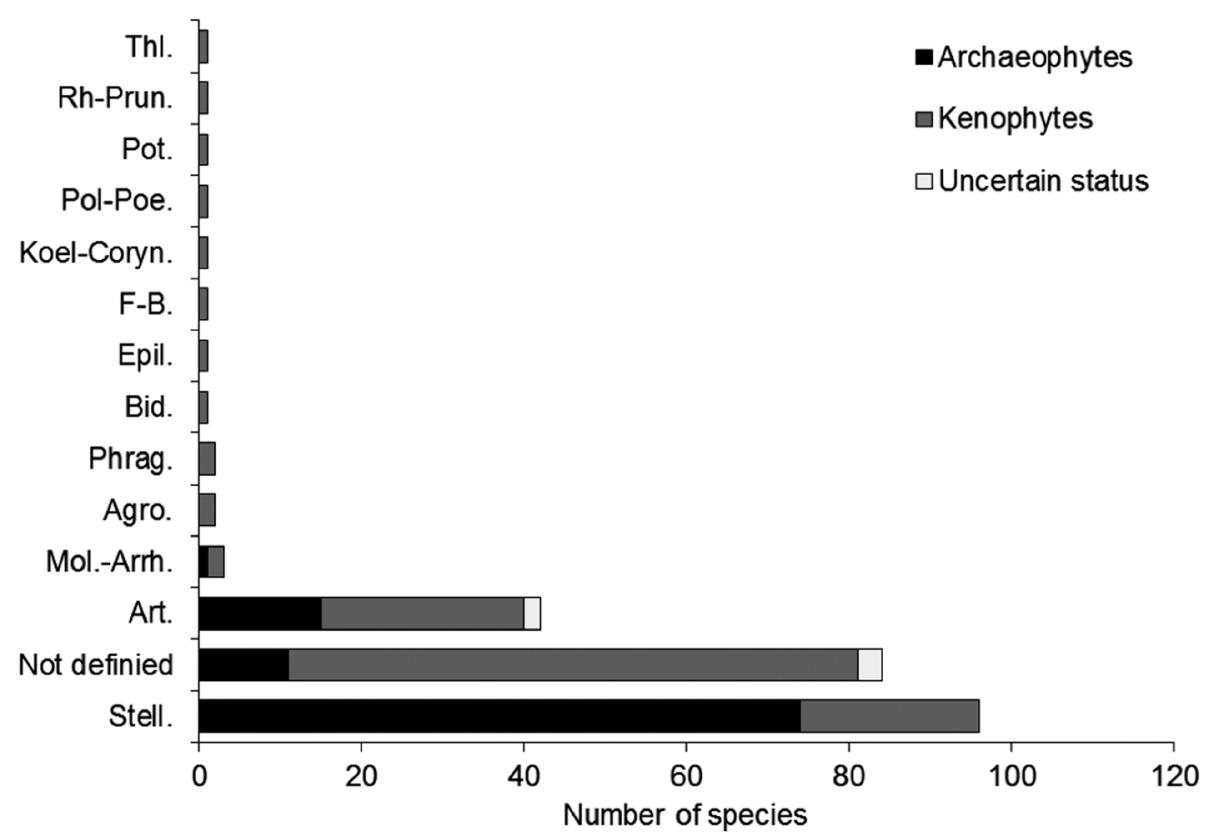

Fig 7. Occurrence of naturalized alien species in phytosociological units

Explanations: Agro. - Agropyretea intermedio-repentis, Art. - Artemisietea vulgaris, Bid. - Bidentetea tripartiti, Epil. - Epilobietea angustifolii, F-B. - FestucoBrometea, Koel-Coryn. - Koelerio glaucae-Corynophoretea canescenti, Mol-A. - Molinio-Arrhenatheretea, Phrag. - Phragmitetea, Pol-Poe. - Polygono arenastri - Poetea annuae, Pot. - Potametea, Rh-Prun. - Rhamno-Prunetea, Stell. - Stellarietea mediae, Thl. - Thlaspietea rotundifolii 
to the whole country. Both archaeophytes and kenophytes represent $78 \%$ of the Rzeszów Foothills alien flora, while for Poland, it is 56\% (Table 1).

In the investigated area, there was a higher percentage of kenophytes than in the neighboring areas. On the Przemyśl Foothills, kenophytes comprise $40 \%$ of alien flora (Wolanin 2014), and in the eastern part of Sandomierz Basin-33\% (Nobis 2008) (Table 1). The proportion of ephemerophytes in the studied area was half of the percentages in the adjacent areas. However, their numbers were significantly greater compared to the literature data (for example Nowiński 1924, 1929a, 1929b, 1930 or Ochyra 1974). Those results confirm a strong human impact on the flora of the studied area. However, high numbers of archaeophytes and naturalized kenophytes indicate that changes in anthropogenic vegetation are not the result of recent years, but involve a longer period of time. A large number of naturalized alien species and an increasing number of casual species (according to historical data) may suggest that the characteristics of the area facilitate the penetration of new species and make their settling relatively easy. Adjacent areas also have a migration path for alien species, but they are not as varied as in the Rzeszów Foothills. In addition, they have more habitats that are less prone to penetration by anthropophytes.

The synanthropy indices constitute measures of environment changes. The analysis showed a relatively high proportion of synanthropic species in the flora of vascular plants in the studied area. The Rzeszów Foothills is characterized by a high anthropophytization index (21.3\%) and kenophytization index (11.7\%), while for the eastern part of the Sandomierz Basin, those indices are $17 \%$ and $8.2 \%$, respectively. This phenomenon is related to the above mentioned modes of spreading of alien species. Archaeophytization index, modernization index and index of floristic fluctuation are similar and relatively high for both areas. A high value of anthropophytization index is correlated with extensive anthropogenic transformations, such as large proportions of economically affected land and also with the presence of large and medium-sized cities with low proportion of natural habitats.

In this study, the status of certain kenophytes was changed in relation to previous publications (Jaźwa 2012). It was due to the fact that the flora distribution was analyzed throughout the whole Rzeszów Foothills area and not only in its western part. The eastern part of the studied region is richer in less transformed habitats, which gave the opportunity for a more objective assessment of the types of habitats occupied by plant species. The most strongly represented families were: Asteraceae, Brassicaceae, Poaceae, Rosaceae and Fabaceae. It is similar to the whole country (Tokarska-Guzik et al. 2014). However, we ascertained a higher percentage of
Brasicaceae and lower of Poaceae than other authors, which may be attributed to the structure of land use of the Rzeszów Foothills.

According to field observations, the status of some species was modified compared to the Tokarska-Guzik et al. publication (2014). Vitis vinifera had spread mainly in river valleys in the Rzeszów Foothills shrublands and, thus, it was considered as a locally established hemiagriophyte. The same was true in case of Populus 'NE42', which was previously planted on roadsides, and is now spreading in ruderal habitats. In some cases, this species formed monocultures and, thus, was considered as a locally established epecophyte. On the other hand, species such as Rosa $\times$ damascena, Rosa majalis, Spiraea alba, S. ×vanhouttei, S. × pseudosalicifolia (obvious refugees from gardens) or Elaeagnus angustifolia, Populus $\times$ canadensis (planted on roadsides) are still characterized by low frequencies in the Rzeszów Foothills area. Moreover, they showed no tendency to spread, usually occupied ruderal habitats and, thus, they were allocated to the diaphytes group. Tokarska-Guzik et al. (2014) classify them as kenophytes.

We detected some species that are still arriving to Poland. The most interesting of them were Abutiolon theophrasti and Brachyactis ciliata. Those species have arrived in recent years into the area of Rzeszów Foothills and are spreading successfully. The first of them appeared in 2009 in the eastern part of Rzeszów Foothills as a single individual in a beet cropping. We expect that within the next few years, it could change its status from diaphyte to epecophyte. The second one, that is Brachyactis ciliata, was noted for the first time in Cracow (Guzik 2002, 2003), and subsequently in Kielce (Bróż \& Podgórska 2005), Tarnobrzeg (Szymański 2010), Rzeszów (Oklejewicz et al. 2012) and, finally, was found at a transfer train station in the Żurawica Rozrządowa (Stadnicka-Futoma \& Oklejewicz 2013).

All of the invasive species identified in this study are also classified as invasive countrywide (TokarskaGuzik et al. 2014). Their impact in the area is diverse. Some of them act like "weeds" and spread mainly in anthropogenic habitats. That was the case with species such as: Amaranthus retroflexus, Avena fatua, Conyza canadensis, Echinochloa crus-galli, Galinsoga ciliata, G. parviflora, Setaria pumila, S. viridis or Veronica persica which had a lot of localities (over 250 for most of them). Other species occupy large areas and can form monocultures and modify the environment, often reducing local biodiversity (Bais et al. 2003; Callaway et al. 2005; Moron et al. 2009). Due to their effect, they are referred to as "transformers" (Richardson 2000). In the Rzeszow Foothills, the following species belong to this group: Acer negundo, Aster novi-belgii, Echinocystis lobata, Elodea canadensis, Impatiens 
glandulifera, I. parviflora, Padus serotina, Quercus rubra, Reynoutria japonica, $R$. sachalinensis, Robinia pseudoaccacia, Rudbeckia laciniata, Solidago canadensis, S. gigantea. Most of them penetrate natural habitats and abandoned fields, limiting the growth of other species. In addition, Echinocystis lobata, Impatiens glandulifera, Robinia pseudoaccacia, Solidago canadensis, $S$. gigantea enter protected habitats - similarly as in other areas (Tokarska-Guzik 2005b). They are classified as some of the most dangerous invasive species in Poland (Anioł-Kwiatkowska \& Śliwiński 2009; Dajdok \& Tokarska-Guzik 2009; Tokarska-Guzik et al. 2014). Together with Erigeron annuus and Rudbeckia lacini$a t a$, they were assigned - based on the validation test (Domaradzki et al. 2013 and references cited therein) - to the highest risk class, as the species with a high probability of threatening natural plant communities. Importantly, those species exhibit similar spreading trends in other European countries (Olaczek 1998; Kowarik 2002; Pyšek et al. 2002).

We also observed species whose impact is still not known and/or observable according to the abovementioned considerations but which, in recent years, maintained their localities and tended to remain as "transformers". Such species included: Helianthus tuberosus, Heracleum mantegazzianum, Lupinus polyphyllus and Trifolium patens, already included in the "transformers" group in other areas (Tokarska-Guzik et al. 2014). Other species classified as invasive belong to the group of non-harmful species.

The invasive plant group also comprises species not established as anthropophytes yet, but having high invasive potential. For example, Miscanthus sacchariflorum, according to Aniok-Kwiatkowska \& Śliwiński (2009) and later by Łuczaj (2011), can be included in this subgroup. This taxon appeared once in the western part of the study area, in a semi-natural meadow habitat. It was observed in the eastern part of the Rzeszów Foothills too, but as a cultivated plant with the escalating escaping tendency.
Despite a large proportion of agricultural landscape, segetal habitats were less exposed to penetration by alien plants and, therefore, weed biodiversity in such habitats was low. Many potential invasive species in such habitats were probably eliminated by the use of pesticides and modern techniques of agriculture. Some species were associated with the railway line No. 91 on the route Rzeszów-Przeworsk. Almost every research unit square contained a few species from the analyzed kenophyte groups. It confirmed the strong flora synanthropy and advanced process of penetration of alien species into the native communities. In recent years, a significant spread of knotweed and giant hogweeds has been recorded. A large number of localities of species such as goldenrod is associated with an enormous amount of wastelands. Relatively few stands of species such as Quercus rubra and Padus serotina are related with distinctly small areas of trees in the whole region, especially in the western part.

There are also two native species in Poland which appear to be regional kenophytes, i.e. Puccinelia distans and Rosa pendulina. They occupied ruderal habitats outside their natural range. These problematic species were excluded in this paper.

\section{Conclusion}

The Rzeszów Foothills area is conducive to the appearance of new alien species, especially the invasive ones. This is caused by external factors, mainly by those mentioned by Hulme (2005), including: strongly modified habitats in the first place, overuse of chemicals, fragmentation of ecosystems, abandonment of arable land and also by migration routes. The analysis of the synanthropic flora of the Rzeszów Foothills contributes to the understanding of the phenomenon of invasions. Such studies encourage monitoring of alien species and may prevent their further penetration. They also emphasize the role of linear corridors (network of roads and railways) in the invasion in this particular area. 


\section{References}

AnioŁ-Kwiatkowska J. \& ŚLiwiński M. 2009. Obce rośliny energetyczne - zagrożenie dla flory Polski. Pamiętnik Puławski 150: 35-44.

Bais H. P., Vepachedu R., Gilroy S., Callaway R. M. \& VIVANCO J. M. 2003. Allelopathy and exotic plant invasion: from molecules and genes to species interactions. Science 301: 1377-1380.

Bróż E. \& Podgórska M. 2005. Symphyotrichum ciliatum (Brachyactis ciliata) (Asteraceae) w Polsce. Fragm. Flor. Geobot. Polonica 12(2): 291-299.

Callaway R. M., Ridenour W. M., Laboski T., Weir T. \& Vivanco J. M. 2005. Natural selection for resistance to the allelopathic effects of invasive plants. J. Ecol. 93: 576-583.

Dajdok Z. \& Tokarska-Guzik B. 2009. Doliny rzeczne i wody stojące jako siedlisko gatunków inwazyjnych. In: Z. DAJDOK, P. PAWLACZYK (eds.). Inwazyjne gatunki roślin ekosystemów mokradłowych Polski, pp. 24-30. Wyd. Klubu Przyrodników, Świebodzin.

Domaradzki K., Dobrzański A. \& Jezierska-Domaradzka A. 2013. Invasive plants - occurrence, importance and threat to biodiversity. Progres in plant protection 53(3): 613-620.

GuzIK J. 2002. Hałda Huty im. T. Sendzimira w Krakowie miejscem występowania interesujących obcych gatunków roślin. Sesja naukowa: Hałda poprzemysłowa - obiekt obserwacji procesów biologicznych, pp. 7. Uniwersytet Śląski w Katowicach.

Guzik J. 2003. Hałda Huty im. T. Sendzimira w Krakowie miejscem występowania interesujących obcych gatunków roślin. Arch. Ochr. Środ. 29(2): 13-19.

Hulme P. E. 2005. Nursery crime: agriculture as victim and perpetrator in the spread of invasive species. Crop Sci. Technol., British Crop Prot. Council: 733-740.

Hulme P. E., PyšeK P., Nentwig W. \& Vilà M. 2009. Will threat of Biological Invasions Unite the European Union. Science 324: 40-41.

Inderjit S., Seastedt T. R., Callaway R. M., Pollock J. L \& KAUR J. 2008. Allelopathy and plant invasions: traditional, congeneric, and bio-geographical approaches. Biol. Invasions 10: 875-890.

JACKOWIAK B. 1990. Antropogeniczne przemiany flory roślin naczyniowych Poznania. Wyd. Nauk. UAM, seria Biologia, 42, 232 pp. Poznań.

JACKOWIAK B. 1998. Struktura przestrzenna flory dużego miasta. Studium metodyczno-problemowe. Prace Zakładu Taksonomii Roślin UAM w Poznaniu 8: 1-227.

JAźwA M. 2012. Kenofity zachodniej części Przedgórza Rzeszowskiego. Fragm. Flor. Geobot. Polonica 19(2): 197-199.

KondRaCKi J. 1994. Geografia Polski. Mezoregiony fizycznogeograficzne. 340 pp. PWN Warszawa.

Kondracki J. 2011. Geografia regionalna Polski. 444 pp. Wyd. Nauk. PWN, Warszawa.

Kornaś J. \& Medwecka-Kornaś A. 2002. Geografia roślin, pp. $636+32$. Wyd. Nauk. PWN, Warszawa.

KOWARIK I. 2002. Biologische Invasionen in Deutschland: zur Rolle nichteinheimischer Pflanzen. In: I. KOWARIK \&
U. StARfinger (eds.). Biologische Invasionen. Herausforderungzum Handeln. Neobiota 1: 5-24.

Lambdon P. W., Pyšek P., Basnou C., Hejda M., Arianoutsou M., Essl F., Jarošik V., Pergl J., Winter M., Anastasiu P., Andriopoulos P., Bazos I., Brundu G., CelestiGrapow L., Chassot P., Delipetrou P., Josefsson M., Kark S., Klotz S., Kokkoris Y., Kuhn I., Marchante H., Perglova I., Pino J., Vilà M., Zikos A., Roy D. \& Hulme P. E. 2008. Alien flora of Europe: species diversity, temporal tends, geographical patterns and research needs. Preslia 80: 101-149.

ŁuCZAJ Ł. 2011. Miscanthus sacchariflorus (Poaceae) - nowy potencjalnie inwazyjny gatunek na Pogórzu Karpackim. Fragm. Flor. Geobot. Polonica 18(1): 192-194.

ŁuCZyckA-Popiel A. 1983. Zbiorowiska synantropijne terenów kolejowych Przeworska, Stalowej Woli i Rozwadowa. Rocz. Przem.. 22-23: 363-375.

Mack R. N., Simberloff D., Londdale W. M., Evans H., Clout M. \& Bazzaz F. A. 2000. Biotic invasions: causes, epidemiology, global consequences, and control. Ecol. Appl. 10(3): 689-710.

Matuszkiewicz W. 2006. Przewodnik do oznaczania zbiorowisk roślinnych Polski. In: J. B. FALIŃsKi (ed.). Vademecum Geobotanicum 3, 537 pp. Wyd. Nauk. PWN, Warszawa.

Mirek Z., Piękoś-Mirkowa H., Zając A. \& Zając M. 2002. Flowering plants and pteridophytes of Poland. A checklist. In: Z. MireK (ed.). Biodiversity of Poland, 1, 442 pp. W. Szafer Institute of Botany, Polish Academy of Sciences, Kraków.

Moroń D., Lenda M., Skórka P., Szentgyörgyi H., Settele J. \& WoyciechowsKi M. 2009. Wild pollinator communities are negatively affected by invasion of alien goldenrods in grassland landscapes. Biol. Conserv. 142: $1322-1332$.

NoBis A. 2008. Rośliny naczyniowe wschodniej części Kotliny Sandomierskiej. Prace Botaniczne UJ 42: 1-341.

NowiŃski M. 1924. Zapiski florystyczne z płd-wsch krańca Kotliny Sandomierskiej. Acta Soc. Bot. Pol. 2(1): 10-14.

NowiŃski M. 1929a. Zespoły roślinne Puszczy Sandomierskiej II. Kosmos, ser. A, 54: 595-674.

NowiŃski M. 1929b. Stosunki geobotaniczne południowowschodniego krańca Puszczy Sandomierskiej. Rozpr. Wydz. Mat.-Przyr. PAU, ser. A/B 67: 375-541.

NowiŃski M. 1930. Zespoły roślinne Puszczy Sandomierskiej. III. Roślinność i znaczenie dla rolnictwa torfowisk niskich z okolic ujścia Wisłoka do Sanu, w południowowschodniej części dawnej Puszczy Sandomierskiej. Prace Rol.-Leśne PAU. 3: 1-90.

Ochyra R. 1974. Notatki florystyczne z południowowschodniej części Kotliny Sandomierskiej. Zesz. Nauk. Uniw. Jagiell. Prace Bot. 2: 161-173.

Oklejewicz K., Puszkar L. \& Wolanin M. 2012. Stanowisko Symphyotrichum ciliatum (Asteraceae) w Rzeszowie. Fragm. Flor. Geobot. Polonica 19(1): 197-199.

OLACZEK R. 1998. The synanthropization of plant cover in the protected areas as a scientific and conservation 
problem. In: J. B. FAliński, W. AdAmowski \& B. JACKOWIAK (eds.). Synantropization of plant cover in new Polish research. Phytocoenosis 10 (N.S.) Suppl. Cartogr. Geobot. 9: 275-279.

Pimentel D., McNair S., Janecka J., Wightman J., Simmonds C., O’Connell C., Wong E., Russel L., Zern J., Aquino T. \& Tsomondo T. 2001. Economic and environmental threats of alien plant, animal, and microbe invasions Agr. Ecosys. and Environ. 84: 1-20.

Pyšek P., Richardson D. M. \& Rejmánek M., Webster G. L., Williamson M. \& Kirschner J. 2004. Alien plants in checklists and floras: towards better communication between taxonomists and ecologists. Taxon 53(1): 131-143.

PYŠEK P., SÁdlo J., MANDÁk B. 2002. Catalogue of alien plants of the Czech Republic. Preslia 74: 97-186.

Richardson D. M., Pyšek P., Rejmánek M., Barbour M. G., Panetta F. D. \& West C. J. 2000. Naturalization and invasion of alien plants: concepts and definitions. Diversity Distrib. 6: 93-107.

Stadnicka-Futoma A. \& Oklejewicz K. 2013. Nowe stanowisko Symphyotrichum ciliatum (Asteraceae) na Przedgórzu Rzeszowskim. Fragm. Flor. Geobot. Polonica 20(2): 386-388.

SzAFER W. \& ZARZyCKi K. (eds.). 1977. Szata roślinna Polski, I, wyd. 3, pp. 615. PWN, Warszawa.

SzYMAŃSki W. M. 2010. Nowe stanowiska Symphyotrichum ciliatum (Asteraceae) w Polsce. Fragm. Flor. Geobot. Polonica 17(2): 415-416.

ToKARskA-GuZIK B. 2005a. The Establishment and Spread of Alien Plant Species (Kenophytes) in the Flora of Poland. Prace naukowe Uniw. Śląskiego w Katowicach 2372: 1-192.

TOKARSKA-GuZIK B. 2005b. Invasive ability of kenophytes occurring in Poland: a tentative assessment. In: W. Nentwig, S. Bacher, M. J. W. Cock, H. Dietz, A. Gigon \& R. Wittenberg (eds.). Biological Invasions - From Ecology to Control. Neobiota 6: 47-65.

Tokarska-Guzik B., Dajdok Z., Zając M., Urbisz A. \& DANIELEWICZ W. 2011. Identyfikacja i kategoryzacja roślin obcego pochodzenia jako podstawa działań praktycznych. In: Z. KĄCKI \& E. STEFAŃSKA-KRZACZEK (eds.). Synantropizacja w dobie zmian różnorodności biologicznej. Acta Bot. Siles. 6: 23-53.

TOKARsKa-GuZiK B., DAJdok Z., ZajĄC M., ZająC A., UrbisZ A., Danielewicz W. \& HoŁdyński C. 2014. Rośliny obcego pochodzenia w Polsce ze szczególnym uwzględnieniem gatunków inwazyjnych. 197 pp. Generalna Dyrekcja Ochrony Środowiska, Krzywe.

Valéry L., Hervé F., Lefeuvre J. \& Simberloff D. 2009. Ecosystem-level consequences of invasions by native species as a way to investigate relationships between evenness and ecosystem function. Biol. Invasions 11: 609-617.

Wilk Ł. 2004. Notatki florystyczne z Podgórza Rzeszowskiego (Kotlina Sandomierska). Fragm. Flor. Geobot. Polonica 11: 93-103.

Wolanin M. 2014. Geobotaniczne aspekty i flora roślin naczyniowych Pogórza Przemyskiego. Prace Botaniczne UJ 47: 1-383.

ZAJĄC A. 1978. Założenia metodyczne "Atlasu rozmieszczenia roślin naczyniowych w Polsce”. Wiad. Bot. 22: $145-155$.

ZaJĄC A. 1979. Pochodzenie archeofitów występujących w Polsce. Rozpr. habil. Uniw. Jagiell, 29: 1-213. Druk UJ w Krakowie.

ZaJAe A. 1987a. Studies on the origin of archeophytes in Poland. Part II. Taxa of Mediterranean and AtlanticMediterranean origin. Zeszyty Nauk. Uniw. Jagiell. 790, Prace bot. 14: 7-50.

ZAJĄC A. 1987b. Studies on the origin of archeophytes in Poland. Part III. Taxa of Irano-Turanian, Euro-SiberianIrano-Turanian and Medieterraean-Irano-Turanian origin. Zeszyty Nauk. Uniw. Jagiell. 834, Prace bot. 15: 93-129.

ZAJĄC A. 1988. Studies on the origin of archeophytes in Poland. Part IV. Taxa of Pontic-Pannonian, Mediterraneo-South Asiatic, South Asiatic and Middle Europaean origin. Archaeophyta anthropogenea. Archaeophyta resistentia. Archaeophytes of unknown origin. Zeszyty Nauk. Uniw. Jagiell. 872, Prace bot. 17: 23-51.

Zając A., Zając M. \& Tokarska-GuZik B. 1998. Kenophytes in the flora of Poland: list, status and origin. In: J. B. Faliński, W. Adamowski \& B. Jackowiak (eds.). Synanthropization of plant cover in new Polish research. Phytocoenosis 10 (N.S.) Suppl. Cartogr. Geobot. 9: 107-116.

ZAJĄC M. \& ZaJĄC A. 2009. Apophytes as invasive plants in the vegetation of Poland. Biodiv. Res. Conserv. 15: $35-40$. 
Appendix 1. List of naturalized alien plant species in the Rzeszów Foothills together with their frequency and status of invasive

Explanations: Frequency (F.): 1 - very rare (1-12 stands), 2 - rare (13-56), 3 - uncommon (57-112), 4 - quite often (113-168), 5 - often (169-224), 6 - very often (225-280), 7 - common (281-334); Status (Stat.): n.i. - not invasive, invasive species (N.H. - not harmful, P.I. - potentially invasive, T - transformes, W - weeds)]

1. Archaeophytes: Aethusa cynapium L. subsp. agrestis [3; n.i.], Agrostemma githago [1; n.i.], Alopecurus myosuroides [1; n.i.], Anagallis arvensis [7; n.i.], Anchusa arvensis [1; n.i.], A. officinalis [2; n.i.], Anthemis arvensis [6; n.i], Apera spicaventi [7; n.i], Aphanes arvensis [5; n.i.], A. inexpectata [1; n.i.], Armoracia rusticana [7; n.i.], Artemisia absinthium [2; n.i.], Atriplex nitens [3; n.i.], Avena fatua [7; W], Ballota nigra [6; n.i.], Bromus secalinus [6; n.i.], B. sterilis [1; n.i.], B. tectorum [3; n.i.], Camelina microcarpa subsp. sylvestris [1; n.i.], C. sativa [1; n.i.], Capsella bursa-pastoris [7; n.i.], Carduus acanthoides [3; n.i.], Centaurea cyanus [7; n.i.], Chamomilla recutita [5; n.i], Chenopodium bonus-henricus [1; n.i.], Ch. ficifolium [3; n.i.], Ch. hybridum [3; n.i.], Cichorium intybus [7; n.i.], Conium maculatum [2; n.i.], Consolida regalis [5; n.i.], Coronopus squamatus [1; n.i.], Descurainia sophia [4; n.i.], Digitaria ischaemum [2; n.i.], D. sanguinalis [4; n.i.], Echinochloa crus-galli [7; W], Euphorbia exigua [1; n.i.], E. helioscopia [6; n.i.], E. peplus [2; n.i.], Fallopia convolvulus [7; n.i.], Fumaria officinalis [1; n.i.], F. vaillantii [1; n.i.], Galium spurium [1; n.i.], Geranium dissectum [6; n.i.], G. molle [1; n.i.], G. pusillum [4; n.i.], Hordeum murinum [1; n.i.], Hyoscyamus niger [2; n.i.], Kickxia elatine [1; n.i.], Lactuca serriola [7; n.i.], Lamium album [7; n.i.], L. amplexicaule [3; n.i.], L. purpureum [7; n.i.], Lathyrus tuberosus [4; n.i.], Leonurus cardiaca [3; n.i.], Lepidium campestre [1; n.i.], L. ruderale [3; n.i.], Lithospermum arvense [5; n.i.], Lolium temulentum [1; n.i.], Malva alcea [1; n.i.], M. crispa [1; n.i], M. neglecta [4; n.i.], M. pusilla [2; n.i.], M. sylvestris [4; n.i.], Matricaria maritima subsp. inodora [7; n.i.], Melandrium album [7; n.i.], Myosotis arvensis [7; n.i.], Nepeta cataria [1; n.i.], Neslia paniculata [1; n.i.], Odontites verna [2; n.i.], Onopordum acanthium [2; n.i.], Papaver argemone [1; n.i.], P. dubium [1; n.i.], P. rhoeas [7; n.i.], Pastinaca sativa [7; n.i.], Pisum sativum subsp. arvense [1; n.i.], Raphanus raphanistrum [3; n.i.], Scleranthus annuus [4; n.i.], Senecio vulgaris [7; n.i.], Setaria pumila [7; W], S. viridis [3; W], Sherardia arvensis [1; n.i.], Sinapis arvensis [7; n.i.], Sisymbrium officinale [7; n.i.], Solanum nigrum [5; n.i.], Sonchus asper [6; n.i.], S. oleraceus [7; n.i.], Spergula arvensis [3; n.i.], Thlaspi arvense [7; n.i.], Urtica urens [2; n.i.], Valerianella dentata [1; n.i.], V. locusta [1; n.i.], Verbena officinalis [2; n.i.], Veronica arvensis [7; n.i.], V. polita [2; n.i.], V. triphyllos [2; n.i.], Vicia hirsuta [7; n.i.], V. sativa [1; n.i.], V. tetrasperma [6; n.i.], V. villosa [4; n.i.], Viola arvensis [7; n.i.], V. odorata [3; n.i.]

2. Epecophytes locally naturalized: Abutilon theophrasti [1; n.i.], Aronia melanocarpa [1; n.i.], Erucastrum gallicum [1; n.i.], Physocarpus opulifolius [1; n.i.], Populus NE'42' [2; n.i.], Rudbeckia hirta [2; n.i.], Tanacetum parthenium [2; n.i.]

3. Epecophytes naturalized: Amaranthus albus [1; n.i.], A. blitoides [1; n.i.], A. chlorostachys [2; n.i.], A. lividus [1; n.i.], A. retroflexus [7; W], Ambrosia artemisiifolia [1; P.I.], Anthoxanthum aristatum $[1 ;$ n.i.], Artemisia annua $[1 ;$ n.i.], Aster $\times$ salignus [1; n.i.], A. novae-angliae [1; n.i.], Atriplex hortensis [1; n.i.], A. tatarica [1; n.i.], Brachyactis ciliata [1; P.I.], Bryonia dioica [1; n.i.], Bunias orientalis [4; N.H.], Cardaria draba [3; n.i.], Chamomilla suaveolens [7; n.i.], Chenopodium pedunculare [4; n.i.], Ch. schraderanum [1; n.i.], Ch. strictum [2; n.i.], Ch. suecicum [1; n.i.], Conyza canadensis [7; W], Cornus sericea [1; N.H.], Datura stramonium [1; n.i.], Dianthus barbatus [1; n.i.], Digitalis purpurea [1; n.i.], Diplotaxis muralis [3; N.H.], Elsholtzia ciliata [2; n.i.], Eragrostis albensis [2; N.H.], E. minor [2; n.i.], Fraxinus pennsylvanica [2; N.H.], Galeopsis angustifolia [1; n.i.], Galinsoga ciliata [7; W], G. parviflora [7; W], Helianthus tuberosus [2; N.H.], Hesperis matronalis [1; n.i.], Iva xanthiiflia [1; n.i.], Juglans regia [6; P.I.], Juncus tenuis [6; N.H.], Kochia scoparia [2; n.i.], Lepidium densiflorum [1; n.i.], L. virginicum [1; n.i.], Lycium barbarum [2; n.i.], Lysimachia punctata [1; n.i.], Malva moschata [1; n.i], Medicago $\times$ varia [4; n.i.], Mentha rotundifolia [1; n.i.], Oenothera fallax [1; n.i.], O. glazioviana [1; n.i.], O. oakesiana [1; n.i.], O. subterminalis [1; n.i.], Oxalis corniculata [2; N.H.], O. fontana [7; n.i.], Parthenocissus quinquefolia [1; n.i.], Physalis alkekengi [1; n.i.], Portulaca oleracea [1; n.i.], Prunus domestica [2; n.i.], Reynoutria sachalinensis [1; T], Rhus typhina [2; N.H.], Rosa multiflora [2; n.i.], Salix eriocephala [1; n.i.], Sedum spurium [1; n.i.], Silene dichotoma [1; n.i.], Sinapis alba [2; n.i.], Sisymbrium altissimum [1; n.i.], S. loeselii [3; n.i.], Sorbaria sorbifolia [1; n.i.], Symphoricarpos albus [2; n.i.], Syringa vulgaris [3; n.i.], Typha laxmannii [1; n.i.], Veronica filiformis [3; N.H.], V. peregrina [1; n.i.], V. persica [7; T], Vicia dasycarpa [1; n.i.], Vitis riparia $[1 ;$ n.i.], Xanthium strumarium $[1 ;$ n.i.]

4. Hemiagriophytes naturalized: Acer negundo [5; W], Aesculus hippocastanum [3; n.i], Aronia $\times$ prunifolia [1; n.i.], Aster lanceolatus [1; n.i.], A. novi-belgii [1; T], A. tradescantii [1; n.i.], Bromus carinatus [4; N.H.], Bryonia alba [1; n.i.], Calystegia sylvatica [1; n.i.], Cerasus vulgaris [2; n.i.], Cuscuta campestris [1; n.i.], Echinops sphaerocephalus [2; n.i.], Epilobium ciliatum [3; N.H.], Erechtites hieracifolia [1; N.H.], Erigeron annuus [7; N.H.], E. ramosus [1; n.i.], Heracleum mantegazzianum [1; P.I.], Inula helenium [1; n.i.], Linum austriacum [1; n.i.], Lolium multiflorum [4; N.H.], Lupinus polyphyllus [1; N.H.], Lycopersicon esculentum [1; n.i.], Medicago sativa [6; n.i.], Prunus cerasifera [2; n.i.], Pyrus communis [4; n.i.], Reynoutria japonica [3; T], Rosa rugosa [3; N.H.], Rumex confertus [3; n.i.], Senecio vernalis [2; n.i.], Solidago canadensis [2; T], Trifolium patens [2; N.H.], Vicia grandiflora [7; N.H.], Vitis vinifera [2; n.i.]

5. Holoagriphytes naturalized: Acorus calamus [1; n.i.], Bidens frondosa [4; T], Echinocystis lobata [7; T], Elodea canadensis [2; T], Impatiens glandulifera [7; T], I. parviflora [7; T], Malus domestica [4; n.i.], Padus serotina [2; T], 
Parthenocissus inserta [4; N.H.], Quercus rubra [3; T], Ribes rubrum [1; n.i.], Robinia pseudoaccacia [7; T], Rudbeckia laciniata $[3 ; \mathrm{T}]$, Solidago gigantea $[7 ; \mathrm{T}]$

6. Uncertian status: Cirsium vulgare [6; n.i.], Erysimum cheiranthoides [5; n.i.], Euphorbia platyphyllos [2; n.i.], E. virgultosa [1; n.i.], Geranium columbinum [2; n.i.]. 